\title{
USE OF PCR TO DETECT CLASSICAL ENTEROTOXINS GENES (ENT) AND TOXIC SHOCK SYNDROME TOXIN-1 GENE (TST) IN STAPH YLO COCCUS AUREUS ISOLATED FROM CRUDE MILK AND DETERMINATION OF TOXIN PRODUCTIVITIESOF S. AUREUS ISOLATESHARBORING THESE GENES
}

\author{
L. Chapaval' , D.H. M oon², J.E. G omes³, F.R. D uarte³, S.M . Tsai
}

1EMBRAPA/ CNPC, CP D10, CEP 62011-970, Sobral, CE, Brasil. E-mail: lea@cnpc.embrapa.br

\begin{abstract}
During a2-year period (2003-2004), 132strains ofStaphylococcus aureus isolated fromcrudemilk (withoutthermal treatment) collected in differentplaces in Piracicaba, São PauloState, Brazil, were investigated for thepresenceof genes for enterotoxins (ent) and toxicshock synd rometoxin-1 (tst). Polymerase-chain reaction (PCR) was performed by using 6 pairs of relevant oligonucleotide primers. N inety isolates (68.18\%) were positive for (47 strains) or 2 (43 strains) toxin genes. The combination of entA and tst showed the highest prevalence (33 strains). The good correlation between PCR results and toxin protein detection and identification by optimum-sensitivity-plate (OSP) test was observed when $44.45 \%$ of strains showed positive for toxin production.
\end{abstract}

KEY WORDS: Enterotoxin, toxic shock syndrometoxin-1, crude milk, Staphylococcus aureus.

RESUMO

USO DA REAÇÃO DA POLIMERASE EM CADEIA (PCR) PARA DETECÇÃO DE GENESDE ENTEROTOXINA (ENT) E GENESDA TOXINA DA SÍNDROME DO CHOQUE TÓXICO (TST)EM STA PH Y LOCOCCU S AUREU S ISOLADOSDO LEITE CRU E DETERMINAÇÃO DA PRODUÇÃO DETOXINASEM ISOLADOSPORTA DORESDESTESGENES. Duranteum período de2anos (20032004), 132 cepas deStaphylococcus aur eus isoladas deleitecru foram coletadas dediferentes regiões dePiracicaba, no Estado deSão Paulo. Foi investigadaa presença dos genes deenterotoxinas (ent) egenes da Toxina-1 da Síndromedo ChoqueTóxico (tst). A reação da pol imeraseem cadeia (PCR) foi executada usando6pares deol igonucleotídeosespecíficos paracadageneemquestão. N oventa e quatro isolados (68,18\%) se mostraram positivos para a presença de um (47 isolados) ou mais genes (43isolados). A combinação da presençadeentA etst mostrou altaprevalência(33isolados). H ouve boa correlação entre a presença do gene e a produção/ detecção da toxina, feita pelo teste dasensibilidadeótima em placas(OSP), quefoi observadaquand o 44,44\% dosisoladosmostraramse positivos para a produção de toxina.

PALAVRAS-CHAVE: Enterotoxina, toxina-1 da síndrome do choque tóxico, leite cru, Staphylococcus aureus.

\section{INTRODUCTION}

Staphylococcal enterotoxins(SEs) areemetictoxins and that causeoffood poisoning in humans. SEshave been classified as members of the pyrogenic toxin superantigen family because of their biological activities and structural relatedness BALABAN \&
Rasooly, 2000; Dinges etal., 2000). Thestaphylococcal enterotoxins (SEs) and toxic shock syndrometoxin-1 (TSST-1) areagroup of low molecular weight proteins. SEs have been classified according to serological differences. They are designated SEA to SEE. Minor epitope differences in SEC group have resulted in a further subdivision into SEC-1, SEC-2 and SEC-3

¿Universidade de São Paulo, Centro de Energia N uclear na A gricultura, Laboratório de Biologia Celular e M olecular, Piracicaba, SP, Brasil.

"Universidade deSão Paulo, Escola Superior deAgricultura “Luiz deQueiroz", Departamento deGenética, Piracicaba, SP, Brasil. 
(Zschöck et al., 2000). TSST-1 commonly causes the toxic shock syndrome in humans and these exoproteinsseem to haveavariety of effectson cells of the immune system (Wood et al., 1991).

Several reportshavedescribed thedevelopmentof PCRs for thedetection of ent and tst genes(BECKERetal., 1998; Jarraud et al., 1999; McLaUChlin et al., 2000; Mehrotra et al., 2000; M ONDAY \& BOHACH, 1999, ZschöCK etal., 2000; Омов etal.,2002). However, itisnoteworthy that thePCR is only ableto demonstratetheexistence of ent and tst genes in Staphylococcus aureus isolates and doesnotprovethat theproduction os SEsproteins occurs. Todemonstratetheability of astrain toproduce sufficient amount of SEs protein to induce disease, bioassaysor immunological methodsfor thedetection of SEs protein must be developed.

The purposes of this study were to analyze the distribution of genesentA to entE and tst in S. aureus isolated from crude milk, in Piracicaba, São Paulo State, Brazil and the in vitro production of SEs and TSST -1 by isolates harboring the respective genes.

\section{MATERIALSAND METHODS}

\section{Sources and strains of $S$. aureus}

One-hundred thirty-two (132)S. aureus strainswere studied. Strains were isolated from crude milk originating from Piracicabaand surrounding localities, in São Paulo State, Brazil, colected in 2003 and 2004 using standard methods according to recommendationsof thelnternational Dairy Federation (IDF, 1981). Sel ection wascarried outby samplingonly onestrain per milk sample. Additionally, sixS. aureus isolates previously characterized as producing oneor more toxins were used as reference strains. Three enterotoxin-negative $S$. aureus strains were used as negativecontrols. Sampleswereseeded on Baird-Parker Agar (BP). A gar plateswereincubated at $37^{\circ} \mathrm{C}$ and read after 24 and $48 \mathrm{~h}$. Isolates weresubcultured on nutrient agar (NA) and identified using the following criteria: Gramstaining result, thepresence of catal ase-positive cocci in clumps, coagulaseproduction, acharacteristic haemolysis pattern when plated on sheep blood agar and characterization by using a commercial identification system.

\section{DNA isolation}

TheDNA isolation method of DoYLE \& DoYLE (1990) was modified in order to facilitate the extraction of $S$. aureus DNA. A volume of $2.5 \mathrm{~mL}$ was collected from 5 $\mathrm{mL}$ overnightculturesin $\mathrm{BH}$ I and centrifuged at 14.000 rpm $(20.800 \mathrm{~g})$ for 30 seconds. The supernatant was discarded and the pellet was resuspended in $700 \mathrm{~mL}$ extraction buffer $(1.4 \mathrm{M} \mathrm{NaCl}, 100 \mathrm{mM}$ Tris- $\mathrm{HCl}[\mathrm{pH}$ 8.0], 200mM EDTA [pH 8.0],PVP (polyvinylpyrrolidone) $40 \%$, CTAB (cetyltrimethylammonium bromide) $2 \%$, Proteinase $\mathrm{K} 20 \mathrm{mg} / \mathrm{mL}$ and $\beta$-Mercaptoethanol $0,2 \%$ ). After mixing, the tube was incubated at $65^{\circ} \mathrm{C}$ for 30 minutes with occasional mixing every 10 minutes. N ext, 650 $\mu$ L of chloroform-isoamyl al cohol (24:1)were added and the solution was centrifuged at $14.000 \mathrm{rpm}$ $(20.800 \mathrm{~g})$ for $7 \mathrm{mins}$. The upper aqueous phase was transferred to a $1.5-\mathrm{mL}$ tube and $200 \mu \mathrm{L}$ of extraction buffer without ProteinaseK wereadded. Thesolution was gently mixed and $650 \mu \mathrm{L}$ of chloroform-isoamyl alcohol (24:1) was added and centrifuged at 14.000 rpm(20.800g) for $7 \mathrm{~min}$. Theupper aqueousphasewas transferred toanew tubeand thepreviouschloroformisoamyl al cohol (24:1) extraction was performed twice more. The DNA was precipitated by adding an equal volume of isopropanol at room temperature, mixing and centrifugation at $14.000 \mathrm{rpm}(20.800 \mathrm{~g})$ for $7 \mathrm{~min}$. The isopropanol was removed and the pellet was washed twice with $70 \mu \mathrm{L}$ of $70 \%$ ethanol. The DNA pellet was dry and ressuspended in 40 $\mu \mathrm{L}$ of TE buffer (10mM Tris- $\mathrm{HCl}[\mathrm{pH} 8,0], 1 \mathrm{mM}$ EDTA [pH 8,0] and 10 $\mathrm{mg} / \mathrm{mL}$ ofRN Ase)and incubated at $37^{\circ} \mathrm{C}$ for 30 minutes.

\section{PCR primers}

Primersfor PCR weresynthesized by Promicroä(São Paulo, Brazil) based on sequences published by Mehotra et al. (2000) for entA to entE and tsst genes (Table 1).

\section{Polymerase-chain reaction (PCR)}

PCR amplification was performed in $25 \mathrm{~mL}$ reaction mixture containing (20 to $90 \mathrm{ng} / \mu \mathrm{L}$ of DN A , 1X PCR-buffer, $3 \mathrm{mM} \mathrm{M} \mathrm{gCl2,} \mathrm{200uM} \mathrm{dN} \mathrm{TPs,}$ 20 pmols of primers ( $40 \mathrm{pmol}$ forsed gene) and 1.25 $U$ of Taq DNA polymerase. The following amplification program was carried out at $96^{\circ} \mathrm{C}$ for $5 \mathrm{~min}$ followed by $35 \mathrm{cycles}$ of $2 \mathrm{~min}$ at $94^{\circ} \mathrm{C}, 2 \mathrm{~min}$ at $54^{\circ} \mathrm{C}$ and $1 \mathrm{~min}$ at $72^{\circ} \mathrm{C}$ and a final extension at $72^{\circ} \mathrm{C}$ for $7 \mathrm{~min}$ in a Gene A mp PCR System 9700 thermocycler. PCR products were visual ized after eletrophoresis on $2 \%$ agarose gel stained with ethidium bromide and the product size estimated using a 100-bp DN A ladder.

\section{Production and detection of Enterotoxins (SEA- SEE) and TSST-1}

All strainsweretested for enterotoxinsA to E (SEASEE) and TSST-1 by cellophane-over-agar method for enterotoxin production (H ALLENDER, 1965; JARVIS et al., 1970; RoBBinsetal ., 1974), and theoptimum-sensitivitypalte (OSP) method for enterotoxin detection and identification (RobBins et al., 1974). 
Table 1 - Sequences used for PCR enterotoxins genes (ent) and toxic shock syndrome toxin-1 gene (tst) detection.

\begin{tabular}{|c|c|c|c|c|}
\hline Gene & Primer & Sequence & $\begin{array}{l}\text { Location inside } \\
\text { the gene }\end{array}$ & $\begin{array}{l}\text { Amplicon } \\
\text { size }\end{array}$ \\
\hline \multirow[t]{2}{*}{ entA } & GSEAR-1 & GGTTATCAATGTGCGGGTGG & $349-368431-450$ & 102 \\
\hline & GSEAR-2 & CGCCACTTITTCTCTTCGG & & \\
\hline \multirow[t]{2}{*}{ entB } & GSEBR-1 & GTATGGTGGTGTAACTGAGC & $666-685810-829$ & 164 \\
\hline & GSEBR-2 & CCAAATAGTGACGAGTTAGG & & \\
\hline \multirow[t]{2}{*}{ entC2 } & GSECR-1 & AGATGAAGTAGTTGATGTGTATGG & $432-455863-882$ & 451 \\
\hline & GSECR-2 & CACACTITTAGAATCAACCG & & \\
\hline \multirow[t]{2}{*}{ entD } & GSEDR-1 & CCAATAATAGGAGAAAATAAAAG & $492-514750-769$ & 278 \\
\hline & GSEDR-2 & ATTGGTATIIIITTCGTTC & & \\
\hline \multirow{2}{*}{ entE } & GSEER-1 & AGGTIIITCACAGGTCATCC & $237-257425-445$ & 209 \\
\hline & GSEER-2 & CTITITTTCTTCGGTCAATC & & \\
\hline \multirow[t]{2}{*}{ tst } & GTSSTR-1 & АССССТGTTСССТТАТСАТС & 88-107 394-113 & 326 \\
\hline & GTSSTR-2 & TाTCAGTATITGTAACGCC & & \\
\hline
\end{tabular}

Table2 - Genotypic (PCR) and phenotypic results forS. aur eus toxins detection from crudemilk, Piracicaba, São Paulo, Brazil (2003-2004).

\begin{tabular}{lcclcc}
\hline $\begin{array}{c}\text { Gene } \\
\text { (genotype) }\end{array}$ & Isolates & Genedetection (\%) & Toxin (phenotype) & Isolates & $\begin{array}{c}\text { OSP Toxin } \\
\text { detection method (\%) }\end{array}$ \\
\hline Total & 90 & 68.18 & Total & 40 & 44.44 \\
entA & 61 & 67.78 & SEA & 14 & 35.00 \\
entB & 30 & 33.33 & SEB & 27 & 67.50 \\
entC2 & 5 & 5.56 & SEC2 & 5 & 12.50 \\
entD & 0 & 0.00 & SED & 0 & 0.00 \\
entE & 0 & 0.00 & SEE & 0 & 0.00 \\
tst & 38 & 42.22 & TSST-1 & 13 & 32.50 \\
entA +tst & 33 & 36.66 & SEA +TSST-1 & 10 & 25.00 \\
\hline
\end{tabular}

\section{RESULTS}

The reaction with each individual primer pair resulted in amplification of single products when DNA from each reference strain was used as a template. Thesizes of productsobtained from control strains in PCR designs corresponded to thepredicted sizes (Fig. 1). Reproducibility was observed in all tested strains.

Testing for the enterotoxins (ent) and TSST- 1 (tst) genes was performed in all 132 isolates of S. au reus on this study and 90 isolates (68.18\%) were positive for one or two toxin genes. Of these positive strains, 61 (67.78\%) were positive for entA , 30, (33.33\%) for entB, 5 (5.56\%) for entC 2 and 38 (42.22\%) for tst. Also 33 strains (36.66\%) co-amplifiedentA and tst genes. $N$ one of the $90 \mathrm{~S}$. aureus strains carried the entD and entEgenes (Table 2).

The production of SE and TSST - 1 was detected in 40 strains (44.44\%): 14 (35\%) for SEA, 27 (67.5\%) for SEB, 5 (12.5\%) for SEC2 and 13 (32.5\%) for TSST-1 (Table 2).

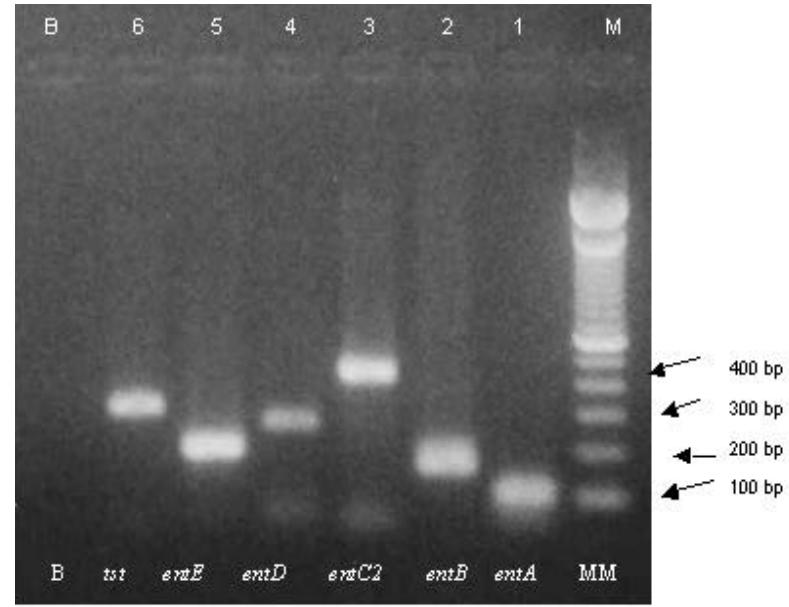

Fig. 1 - Electrophoresis of the PCR fragments generated using DNA extracted according DoyLE \& DoYLE (1990) methodology and primers sets specific for the $S$. aureus enterotoxins genes. LaneM I Hind III molecular marker, 1 entA 102bp, 2 entB 164bp, 3 entC2 451bp, 4 entD 278bp, 5 entE 209bp, 6tst 326bp and B negativecontrol (no DNA). 


\section{DISCUSSION}

Some $S$. aureus strains produce one or more enterotoxigenictoxinsincludingSEA-SEE and TSST1 and these toxins represent the main cause of staphylococcal food poisoning. It has been estimated thatabout $95 \%$ of theseoutbreaksweredueto dassical SEs, such as SEA to SEE (OMOE et al., 2002). The determination of staphylococci enterotoxinstypehas alonghistory of sucessful usein epidemiologicstudies in both clinical and environmental microbiology studies. Thelimitation of all genotipictests is that the presence of the gene does not always necessarily mean that thetoxin will beproduce. Someresearches (N EILL et al., 1990) identified the presence on an entC genein two strains which did not produce detectable levels of SEC toxin when they used the SET-RPLA assay. This situation aboveand many others may be dueto low-level production of enterotoxin below the threshold of detection for the immunological assay. Since the production of enterotoxins by staphylococcal strains can be affected by the growth conditions used (inoculum level, temperature, $\mathrm{pH}$, and water activity) (GENIGEORGIS, 1989), it is possible that for these particular isolates thestandard culture conditions specified for the immunological assays aresuboptimal forgeneexpression. Alternatively, the ent genesmay notbeexpressed dueto mutationseither in the coding region or in aregulatory region (SHARMA et al., 2000). H owever, one major application of the immunological assaysisthetoxin typing of strainsfor epidemiological purposesitisno usually essential to know whether or not a gene is expressed. Fuero et al. (2001) reported that up to $28 \%$ ( 62 out 224 ) of the S. aureus strains generated positive agglutination with oneor two sera and all of them contained ent genes as determined by the PCR method.

In the report by OMOE et al. (2002), analysed 71S. aureus isolates from various sources and 66 (93\%) werefound to be positivefor oneor moreent genes. SÁ et al. (2004) analysed 209 samples from bovine milk and found that 9 strains (4.39\%) were enterotoxin producer being 1 ( $0.49 \%)$ for SED, 3 (1.46\%) for SEE and 3 (1.46) for SEB production. ZsCHÖCK et al. (2000) performed testforenterotoxingenesin 94 field isolates and found $34(36.2 \%)$ S. aureus isolatesweretoxin (enttsst)-gene positive by PCR. Three field strains (3.2\%) wereclassified as carrier of entA -gene, 2isolates $(2.1 \%)$ had entB-genes and 22 (23.4\%) werepositivefor entC gene. TheentD -genewasfound in 4(4.3\%) isolates,tstgeneoccurred as singlegene(3isolates, 3.2\%), and in combination with entC -gene (15field strains, $16 \%$ ) or entA-gene ( 1 isolate, $1,1 \%$ ). None of the $94 \mathrm{~S}$. aureus strains carried entE-gene. Differentworkshavereport extremely variable results from the frequency of SEs among staphylococcal strains (SÁ, 2004; FuEYO et al.,
2001; J JRVIset al., 1970) and from presence of S. aureus enterotoxin genes (BECKER et al., 1998; MCLAUCHLIN et al ., 2000; MenRotra et al ., 2000; SH ARM A et al., 2000). Datafrom thepresent study reported variableresults from frequency of enterotoxin genes and toxin productivies that showed a good relation between detection of SEs and their ent genes.

\section{CONCLUSION}

Thefact that PCR techniqueal lows detection of the genetic potential for enterotoxin production may make it useful as both a screening test and a confirmatory test for enterotoxins actually elicited, as detemined by immunological assays. Theexistence of ent genes in S. aureus isolatesisnecessary for thesestainsto causefood poisoning. However, itisdebatablewhether all ent genepositive strains can cause disease. The combination of both methods is a guarantee for success in diagnostic analisys tests and can also be recommend PCR use a screening test for presence of enterotoxin genes.

\section{References}

Balaban, N. \& Rasooly, A. Staphylococcal enterotoxins. International Journal of Food M icrobiology, v.61, p.1-10,2000.

BeCKer, K.; Roth, R.; Peters, G. Rapid and specific detection of toxigenic Staphylococcus aureus:useof twomultiplexPCR enzyme immunoassays for ammplification and hybridization of staphylococcal enterotoxin genes, exfoliativetoxin genes, and toxicsyndrometoxin-1gene. Journal of Clinical M icrobiology, v.36, p.2548-2553, 1998.

Dinges, M.M.; Orwin, P.M.; Schlievert, P.M. Exotoxins of Staphylococcus aureus. Clinical M icrobiology Review, v.13, p.16-34, 2000.

DOYLE,J.J.T.\&DOYLE, J.L.I solation of plantDNA fromfresh tissue. Focus, v.12, p.13-18, 1990.

Fueyo, J.M.; M artín, M.C.;GonzÁlez-Hevia, M.A.; Mendoza, M.C.Enterotoxin production and DNA fingerprintin Staphylococcus aureus isolated from human and food samples. Relations between genetic types and enterotoxins. International J ournal of Food M icrobiology, v.67, p.139-145, 2001.

Genigeorgis, C.A. Present state of knowledge of staphylococcal intoxication. International J ournal of F ood M icrobiology, v.9, p.327-360, 1989.

Hallender, H.O. Production of large quantities of enterotoxin B, and other staphylococcal toxinsin solid medice. Acta Pathologica M icrobiologica Scandinavica, v.63, p.299-305, 1965.

InTERnATIONAL DaIRY FedARATION (IDF). Laboratory methods for usein Mastitiswork.D ocument, v.132, p.19-26, 1981.

Jarraud, S.; Cozon, G.; Vandenesch, F.; Bes, M.; Etienne, J.; LiNA, G. Involviment of enterotoxin $G$ and I in staphylococcal toxic shock syndrome and staphylococcal carlet fever. Journal of Clinical M icrobiology, v.37, p.2446-2449, 1999. 
Jarvis, A.W. Lawrence, R.C.; Pritchard, G.G. Production of staphylococcal enterotoxins $A, B$ and $C$ under conditions of controlled $\mathrm{pH}$ and aeration. Infectology and Immunology, v.7, p.847-854, 1970.

Mclauchlin, J.; N arayanan, G.L.; Mithani, V.; O'Neill, G. Thedetection of enterotoxinsan toxin shocksyndrome toxin genes in Staphylococcus aureus by plymerase chain reaction. Journal of Food Protection, v.63, p.479488, 2000.

Mehrotra, M.; Wang, G.; Johnson, M. Multiplex PCR for detection of genes for Staphylococcus aureus enterotoxins, exfoliativetoxins, toxicshocksyndrome toxin 1, and methicilin resistance. Journal of Clinical M icrobiology, v.38, p.1032-1035, 2000.

MondaY, S.R. \& BoHACH, G.A. Useof multiplexPCR to detect classical and newly described pyrogenctoxinsgenes in staphylococcal isolates.J ournal of Clinical M icrobiology, v.37, p.3411-3414, 1999.

Neill, R.J.;Fanning, G.R.; Delahoz, F.; Wolff, R.; Gemski,P. Oligonucleotide probes for detection and differentiation of Staphylococcus aureus strains contaning genes for enterotoxin A, B and $\mathrm{C}$ and toxin shock syndrome toxin. International J ournal of Clinical M icrobiology, v.28, p.1514-1518, 1990.

Omoe, K.; Machiko, I.; Simoda, Y.; Dong-Liang, H.; Ueda, S. Detection of seg, she and sei genesin Staphylococcusaureus isolatesand determination of theenterotoxinproductivities of $S$. aureus isolates harboring seg, she or sei genes. Journal of Clinical M icrobiology, v.40, p.857-862, 2002.
Robbins, R; Gould, S.; Bergdoll, M.S. Detecting the enterotoxigenicity of Staphylocccus aureus strains. A pplied M icrobiology, v.28, p.947-950, 1974.

Sá, M.E.P.de; Cunha, M.L.R. da; Elias, A.O.; Victória, C.; LANGONI, H. Importance of Staphylococcus aureus in bovinesubclinical mastitis: presenceof enterotoxins, shock synd rometoxin and relationship with somatic cell count. Brasilian Journal of V eterinary Research and A nimal Science, v.41, p.320-326, 2004.

Sharma, N.K.; ReEs, C.E.D.; Dodd, C.E.R. Development of asingle-reaction multiplexPCR toxintyping assay for Staphyl ococcus aureus strains. A pplied and Environmental M icrobiology, v.66, p.1347-1353, 2000.

Wood, A.C.; Todd, I.; Grockayne, A.; Arbuthnott, J.P. Staphylococcal enterotoxinsand immunesystem. FEM S M icrobiology and Immunology, v.76, p.121-134, 1991.

Zschöck, M; Botzler, D.; Böcher, S.; Sommerhäuser, J.; Hamann, H.P. Detection of genes for enterotoxins (ent) and toxin shock syndroem toxin-1 (st) in mammary isolates of Staphylococcus aureus by polymerase-chain reaction. International D airy J ournal, v.10, p.569-574, 2000.

Received on 3/ 2/ 06

Accepted on 11/ 05/ 06 